\title{
Between Hub Status and Parallelism: Examining the G20-BRICS Dynamics in Global Governance ${ }^{1}$
}

\section{A.F. Cooper}

Andrew F. Cooper - Dphil, Professor, Department of Political Science and Balsillie School of International Affairs, University of Waterloo; 200 University Ave West, Waterloo, Ontario, Canada; E-mail: acooper@uwaterloo.ca

\begin{abstract}
Increasingly, the G20 needs to be examined as a decentred focal point in the global system. The dominant formative image of the G20 has been that of a $21^{\text {st }} \mathrm{C}$ concert of powers. Yet, as witnessed by the ongoing dynamics of the summit process, the G20 has become fragmented. As the G20 has moved away from its apex function, it has become a nexus forum/networked focal point. Of key importance in this context is the role of the BRICS grouping of Brazil, Russia, India, China and South Africa. At the same time as this major challenger is increasingly embedded at the hub of global governance represented by the $G 20$, it is also engaged in a diverse array of parallel initiatives. In terms of their informal modes of operation, the G20 and the BRICS share some marked similarities. As the roles of networked fora are consolidated, the diversity of activities expands to incorporate a range of state and non-state actors. However, at the same time the club culture of both the G20 and the BRICS is contested, reducing the like-mindedness associated with traditional concerts of power.

The conceptual arguments developed in this paper are illustrated and reinforced by recent practices, including the Hangzhou G20 and the Goa BRICS summit. The global system is in the midst of a protracted period of discontinuity characterized by profound and intense tension between the push for a consolidated form of institutional synergy (with the G20 as the hub focal point) and the pull towards potential fragmentation (with the BRICS as the core agent of change). The nature and impact of this dynamic will animate the central debate over global governance in the $21^{\text {st }} \mathrm{C}$.
\end{abstract}

Key words: G20; BRICS; global governance; summit; Hangzhou; Goa

For citation: Cooper A.F. (2017) Between Hub Status and Parallelism: Examining the G20-BRICS Dynamics in Global Governance. International Organisations Research Journal, vol. 12, no 2, pp. 146163 (in Russian and English). DOI: 10.17323/1996-7845-2017-02-146

Increasingly, the G20 needs to be examined as a decentred focal point in the global system. Jolted into action by the 2008 financial crisis, the dominant formative image of the $\mathrm{G} 20$ was as a $21^{\text {st }} \mathrm{C}$ concert of powers bringing together countries from the G7/8 establishment and the cluster of systemically important ascendant countries from the global South. Yet, as witnessed by the ongoing dynamics of the summit process, the G20 has

${ }^{1}$ The editorial board received the article in December 2016. 
become fragmented in terms of its sustained impact on the rules and procedures for a reconfigured global order. Tensions in national policy coordination have constrained institutional effectiveness, introducing an unanticipated degree of fragility, rather than an embedded quality of centrality, to the G20's organizational character.

Of key importance in this context is the role of the BRICS grouping of Brazil, Russia, India, China and South Africa. At the same time as the ascending states - more accurately defined as the BICs - are increasingly embedded in the G20 as the hub institution, they are also engaged in a diverse array of parallel or "routing around" initiatives [Barma, Ratner and Weber, 2007; Chin, 2010]. On the one hand, the BRICS has continued to act as a caucus group meeting on the side of the G20 hub. On the other hand, the BRICS has developed a separate identity that has spilled over through an increasingly elaborate summit process, institutionalization via the New Development Bank (NDB) and a wide number of BRICS networking activities.

This paper highlights the dualism of the G20's shifting role from a club forum at the apex of power to a focal point for an important, albeit informal and loose, process of diffuse networking at both intergovernmental and state-societal/transnational levels. The G20 has lost momentum in terms of its ability to engage members of both the G7/8 establishment [Baker, 2010] and the "rising" BRICS [Alexandroff and Cooper, 2010] on matters related to the reform of international financial institutions, the development of transparent arrangements for mutual assessment, measurement of compliance and coherence in policy development and implementation. Notwithstanding this, the G20 continues to make important contributions to the architecture of global governance. Significantly, many of the key features of the G20 are reproduced rather than rejected by the BRICS. At the intergovernmental level, this is reflected in the importance of the Sherpa process and the connections with associated international organizations and "outreach." At the state/societal level the commonalities between the G20 and the BRICS are seen in the advances in networking through structured dialogues with select civil society organizations.

\section{The G20 and the Overall Trajectory of Global Governance}

Before detailing the operational shifts of the G20, it is important to outline the key features in the trajectory of global governance that underpin this analysis. For Dingwerth and Pattburgh, the analytical and conceptual utility of a global governance perspective is the ability to identify and describe "transformation processes" in world politics [2006, p. 196]. Through an examination of the G20 as an institution of global governance, this paper highlights two transformations associated with the G20 - its emergence as a mechanism of global governance in response to the global financial crisis (GFC), and its subsequent shift from consolidation to fragmentation, or in more conceptual terms, away from its apex function and toward the role of a nexus forum/ networked focal point. 
Investigation of the G20 as a decentred focal point necessitates an acute understanding of the parameters of global governance based on a holistic understanding of the framework within which global governance exists. Biermann, Pattberg, van Asselt et al. have developed a perspective based on "architectures" - the "meta-level" of global governance [2009, p. 15] - as a guiding concept for the analysis of both synergy and conflict between different regimes or other types of institutions across a given issue area. With respect to the G20, the interplay between synergy and conflict is central both in examining intra-G20 processes as well as the G20's interinstitutional interaction and development of global governance. This in turn necessitates a consideration of "functional fragmentation," which belies the G20's initial dominant institutional image [Angeloni and Pisani-Ferry, 2012. See also Cooper and and Pouliot, 2015].

These concepts provide a way to operationalize the system structure of global governance within which the G20 carries out its functions and also to analyze the changes taking place within the G20 as a vehicle for global governance. In particular, these concepts are useful for examining the expanded yet decentred and increasingly diffuse process of $\mathrm{G} 20$ governance in the post-GFC period. As a novel source of innovation in world politics, the G20 represents a unique institutional process through which global governance is practiced in contemporary diplomacy [Cooper, 2012; Cooper and Thakur, 2013; Kirton, 2013; Martin, 2013]. The G20's plurilateral structure is especially critical in this regard, as are the deliberative and direction-setting institutional features that comprise its informal organizational structure [Pentilla, 2009].

\section{Nuancing the Nature of Concerts - Differentiating Between Modern and Postmodern Concerts}

To understand whether or how the G20 can be considered a concert, a brief conceptual discussion of concerts is in order [Ikenberry, 2001]. Conceptually, the discipline of international relations (IR) often fails to appreciate the evolving nature of concerts and the related concept of concert diplomacy.

Kirton [1989] defines concerts as emerging when a seminal shock to the stability of the prevailing order causes an effectively equal, collectively predominant, interdependent group of all great powers to develop institutionalized summit diplomacy and supporting consultative mechanisms in order to provide system stability and create the necessary international order. Kirton continues [1989, p. 3]:

Thus, concerts combine the minimum number of independent actors (only great powers), to mobilize the maximum amount of collective capability (all great powers). They do so not to prevail in the short term on behalf of transient interests with a maximum individual division of the spoils (as in the minimum winning coalitions of balance of power theory), but to predominate over the long term in a system devoid of interdependent great powers left on the outside to cause harm or organize resistance. Inclusion of all the extra great powers (i.e., beyond those required for a minimum winning coalition) removes the policy incentive and 
material power for revisionism from the system at the great power level, while reducing the possibility of a single state having dominant capabilities within.

Traditional concert formations have been highly state-centric, emphasizing institutional forms comprised of the core states in a balance of power system. Kirton's definition highlights the importance of power balancing in traditional concert governance. However, the image of the G20 is different. First, it is questionable whether the G20 is characterized by "power balancing" or "power sharing"/distribution of vulnerability. Second, the G20 is not exclusively comprised of the great powers of the international system, and includes middle-ranking powers as well. Third, a key feature of G20 is that it brings systemic significance and mutual vulnerability, neither of which are predicated on traditional calculations of power.

In the definition of a concert, the precondition of interdependence - an important demarcation between traditional and modern concert diplomacy - adds further complexity. Though Kirton's definition adequately explains the presence of the G7/8 within the international system, the role of the G20 within these definitional parameters is more nuanced. The G20 is distinct from the modern concert of the G7/8 in that it is a source of institutional innovation privileging diplomatic inclusion and co-governance (policy and norm development) by established and emerging powers.

Underlying these forms of concert/club governance is the understanding that clubs in the international system function according to consensus. However, recent refinements to the concert model illustrate that postmodern, plurilateral institutions carry out governance functions in more nuanced ways that need to be explored from an operational perspective. This is especially the case when geography and non-like-mindedness are supplemented via systemic significance as the precondition for group formation.

\section{Is There a "Hub and Spoke" Component with Relation to G8/BRICS?}

The notion of "hub and spoke" implies a centralized network structure between nodes within networked groups. With specific reference to the global economic governance architecture, the role of the G20 as the premiere forum for international economic cooperation does suggest the presence of a hub and spoke component. However, when a decentered view of the G20 is taken vis-à-vis the wider system of global governance occupied by formal institutions such as the United Nations and numerous regional organizations [Luckhurst, 2016], the forum no longer functions as a centralized hub/ node. For this reason, the notion of institutional overlap, as compared to that of hub and spoke, may more accurately describe the position, role and function of the G20 in global governance.

While there are hub and spoke characteristics, from a network perspective the density of connections between nodes differs significantly, with the nature of the relationship and division of labour between the G8 and G20 being more explicitly spelled 
out since 2010. Furthermore, if the G20 is to be examined through a hub and spoke lens there are other institutions and organizations that must be considered, including regional organizations such as the African Union (AU), the Asia-Pacific Economic Cooperation (APEC), the Association of Southeast Asian Nations (ASEAN) and others.

With specific reference to the BRICS process, the G20 has yet to explicitly acknowledge the workings of BRICS summitry in its official communications. As institutions embedded within the G20 framework, G8-BRICS interaction on issues concerning economic governance is interesting when examined through ad hoc G20 groupings which are characterized by significant overlap between G8 and BRICS countries [Schirm, 2011]. The interaction of these countries at the informal diplomatic level precedes that at the level of the G20. The Outreach 5 (O5)/Helleigendamm process was a diplomatic process between the G8 and O5/BRICSAM grouping of China, Brazil, India, South Africa and Mexico [Cooper and Antkiewicz, 2008]. Indeed from this perspective, the $\mathrm{G} 20$ represents a diplomatic space where established and emerging powers can deliberate on an equal institutional footing and in the context of an economic climate different from that in which the 05 diplomatic process took place.

A core component of a decentred G20 is a removal of a hub and spoke structure vis-à-vis the G8 and BRICS. The G20 should serve as a deliberative space on matters of global economic governance where cross-communication between established and emerging powers can occur.

\section{Is There a Sense of Hierarchy Between the G20 and Other Informal Organizations?}

It is important to distinguish between hierarchy and density. When examining the G20 as a focal node within a broader network of actors and institutions, hierarchies in the G20's working relationships should not be used to substitute for density as the measure of interaction. One of the key features of informal governance mechanisms is that there is no formal or legal basis for the delegation of tasks and responsibilities. Thus, from the perspective of hierarchy, there is no explicit hierarchy in terms of the interinstitutional dealings between the G20 and other international organizations, whether formal or informal.

The number of informal international organizations connected to G20 governance has increased in the post-GFC period through the Basel Accords, the Financial Stability Board (FSB), the International Organization of Securities Commissions (IOSCO) and the International Accounting Standards Board (IASB). As Brummer [2012] shows, global economic governance takes place largely through informal agreements, statements and accords. The G20 is a critical piece in this architecture in that it has set out informal delegative patterns with associated international institutions, including formal bodies such as the International Monetary Fund (IMF).

Within a focal point structure of networked nodes in world politics, emphasis is on overlap and complementarity among focal points rather than hierarchy. This is not 
to neglect the continued existence of asymmetrical power or the relative strength of some nodes over others - if the range of informal institutions is examined in a comprehensive manner subtle forms of hierarchy can be discerned, with the G20 occupying a degree of centrality [Vabulus and Snidal, 2011]. This elevated status is evident in the hierarchy of diplomatic priority (as measured by commitment of resources, i.e., time and frequency of meetings/summits) afforded to respective international organizations (IOs) by national governments.

Still, even as the G20 is raised to the level of premier forum for international economic cooperation, the it has been balanced against more nuclear groupings (including regional organizations) by established and emerging powers alike - via the BRICS and the $\mathrm{G} 7$ finance respectively.

In terms of G20 institutional innovations, there is a visible hierarchy as well as a pattern of delegation that extends into the realm of formal IOs, including the IMF. Within this system, the G20 should position itself as a facilitator of cooperation across the "informal" architecture of global governance. This may be achieved by greater openness and communication among nodes where the work and deliberation of these groupings feed into the G20 and vice versa. With regard to the formal side of global governance, there is great need for interaction between the G20 and related informal groupings to the United Nations (UN) as an anchor for "legitimate" (inclusive and representative) global governance.

\section{Are the Nexus/Networks Pointing to Closed or Loose/Open Access?}

If the G20 originally showcased a closed/restricted format, over time it has become an increasingly open-access node. That being said, the openness of the G20 depends upon the extent to which the G20 decentres itself within the global governance system.

From the perspective of the G20 as a grouping of countries, debate about whether the forum is closed or open access is interesting. On the one hand, if one is to look beyond the established/emerging powers, the widening middle-power strata apparent within the G20 supports the claim that, as a network grouping of state-actors in the international system, the $\mathrm{G} 20$ has opened its network to accommodate middle powers into the G20 model rather than remaining an institution comprised solely of large established and emerging countries. On the other hand, it can be argued that the G20 remains a closed network in terms of regional and direct representation to the extent that Africa and the Middle East remain disproportionately underrepresented in the G20's makeup.

\section{The "Phases" of G20 Governance in Operation: Centralization and Decentralization as Motifs}

While the concept is not widely addressed, there is reference in the literature on the early G20 leaders' process to the notion of a "focal point" to describe the G20's func- 
tion as a global governance forum. This early description links the G20 as a focal point to its early role as an apex forum. At the time, the G20 could be described as a "constructed focal point" around which state actors converge at the level of global governance and through which "policy direction is coordinated among key actors at the hub of decision making" [Cooper 2010, p. 752; Cooper and Bradford, 2010, p. 4. See also Garrett and Weingast, 1993; Cooper and Thakur, 2013; Luckhurst, 2016]. However, as international policy coordination has become more fragile over the course of the G20 process and member countries have increasingly worked with regional political economic arrangements in tandem with their involvement in the G20, the G20 has played an increasingly diffuse and networked role in global economic governance. This has subsequently impacted the parameters defining "focal points" in that emphasis is placed on how the G20 nexus position underlies the definitional parameters of its focal point position.

In the post-crisis period the $\mathrm{G} 20$ has needed to carry out both crisis and steering functions. It is at this juncture that the crisis committee/steering committee framework is in need of reappraisal. It is here where the G20 as a focal point holds significant analytical weight.

In the immediacy surrounding the GFC the G20 was deemed a necessary institutional arrangement to stem the crisis. As the global political economic context has evolved over the post-crisis period, so too has the institutional innovation created from its wake. Whereas the prevailing assumption was that the G20 would transform from crisis to steering committee as the immediacy of the crisis faded, the current process of the forum suggests the occurrence of a broader trend in G20's existence as a leader/ summit level institution. The role of the G20 is shifting as it is decentring from the apex of the global economic governance architecture, and as it transitions to a networked focal point there is a greater emphasis on nexus functions such acting as a conduit for a wider range of actors and issue-areas in the governance architecture. Whereas earlier calls were made for the G20 to become more centralized and formalized while shifting from a "crisis" to a "steering" committee, fragmentation of the G20 process adds nuance to this argument, as highlighted in this paper and other studies. Rather than, or at least prior to, consolidating into a steering committee, the G20's core governance role and function as a "focal point" in the global governance architecture should be consolidated - shifting the emphasis from the G20 as an apex forum to that of a nexus forum.

The current decentring of the G20 is the result of several factors, including the lessened urgency of the crisis, idiosyncrasies in international cooperation and policy coordination (resulting in policy differentiation, divergence and competition), the increasing centrality of non-state actors in the orbit of G20 governance (a function of the pluralization of global order, and the expansion of the G20 agenda and deviation from priorities among G20 members.

The themes of decentralization of the G20 parallel the transition of the G20 from a core role and function as an apex forum in the immediate GFC period, to a role as a nexus forum in the later phase of the post-GFC period. 
The role of apex forums is highlighted by their function in the development of principles and norms as well as the transmission and delegation of concrete governance tasks/responsibilities. Baker [2010, p. 58] states that the defining feature of apex forums is their "quest to oversee and set the strategic priorities, agendas and normative parameters for the entire institutional complex of global financial governance."

Following the summits in Washington, London and Pittsburgh (2008-2009) the image of the G20 as serving the functions of a crisis committee/apex forum was crystalized, reflecting consolidation of concerted governance response in the immediate wake of the GFC. This unity was marked by convergent and concerted global governance responses across these summits. At Washington and London, the focus was on promoting a collective stimulus for the global economy, along with renewed instruments of financial and regulatory reform, the maintenance of global trade flows and the avoidance of protectionist measures. At Pittsburgh, the focus was on the establishment of the G20 Framework on Strong, Sustainable and Balanced Growth/Mutual Assessment Process (MAP) and on institutionalization of G20 as "premier forum for global economic cooperation."

Across these three summits, the G20 worked to establish the framework that would outline the governance functions and parameters of the G20 and to formalize relationships with traditional international financial institutions (IFIs). Further, it established new international institutions through the creation of delegation relationships - the Mutual Assessment Process (MAP) with the IMF, the Organisation for Economic Cooperation and Development (OECD), Offshore Financial Centers (OFCs) and the Financial Stability Board (FSB). The dual objective of recalibrating and innovating has worked to bolster the network of organizations that comprise the global economic governance architecture.

\section{Fragmentation: Differentiation and Diffusion of the G20 Process}

By way of contrast to the image of collective animation of apex power in the first three summits, the latter forums have been seen as part of a phenomenon of diffusion and decentralization. Toronto was held amid the Eurozone crisis part I, with a fragmented consensus within the G20 on stimulus versus fiscal consolidation and austerity measures, and a shift toward policy differentiation as a result of differing circumstances. At Seoul, differences emerged over competitive currency policies (including the U.S. strategy of quantitative easing (QE2) and China's devaluation of the renminbi). Moreover, the emphasis on development as a dimension of G20/global economic governance (illustrated most notably by the Seoul Consensus on Development), revealed a move away from the core agendas of Washington, London and Pittsburgh. Seoul also featured a broadened institutionalization of the G20, including the creation of different portfolios at the sub-state/ministerial level (i.e., foreign and agricultural ministers) and expanded representation through the inclusion of five non-G20 countries representing regional organizations and Global Governance Group (3G) countries [Cooper and 
Momani, 2014]. Cannes, amid the heightening of the Eurozone/Greece crisis, featured further fragmentation and conflict that overshadowed priority issue areas. Only a fraction of the heavy agenda - including the formalization of the Troika process, the expanded institutionalization of the FSB, the extended role of the Business 20 and the Gates Foundation as insider [Cooper, 2013] - was discussed or agreed. Los Cabos emphasized green growth and financial inclusion, as well as the fading London commitment to financial regulation amid the ongoing Eurozone crisis. The use of "delay tactics" by core Eurozone countries - such as waiting for concessions from other parties - was particularly noteworthy as was as the contentious issue of if and how G20 countries should or could contribute to a European bailout.

\section{Causes Underlying the Fragility of G20 Governance}

Fragility of the G20 process is attributed to the strains of domestic pressures on G20 governments. This is manifest through criticisms of protectionist measures, and competitive as opposed to complementary monetary policies. These conflicts have brought G20 countries to the brink of two currency wars - the first in the lead up to the Seoul summit and the second in the lead up to the St. Petersburg summit.

Though the emergence of the G20 is an institutional innovation in and of itself, increasing fragility of the forum's organizational character parallels several broader trends in global governance. There are two especially significant dynamics. First, there has been a rebalancing of norms away from unified global arrangements in favour of more nuanced approaches that take account of national circumstances. Second, the regional arrangements in the global economic governance architecture have been expanded, with the regional institutionalization of multilateral development banks as a case in point (see [Chin, 2010]).

Given the formative capacity of the G20 to identify patterns of reform as well as to bring together a novel diplomatic arrangement of actors (both established and emerging, state and non-state) the fragility of G20 governance must be understood in the context of the wider process of institutional change, rather than taken as a failure of the institution. The core of this institutional transformation is captured by the G20's shift away from its consolidated apex function as a crisis committee, toward a nexus function as a networked focal point.

\section{Embedding the G20 within the Global Governance Architecture: Operationalizing the G20 as a "Focal Point"}

Biermann points out that a theoretical approach to networking amongst international organizations has remained largely absent from the international relations literature [Biermann, 2008, p. 152]. Their study of international organizational networking among formal international organizations argues that the neoliberal-neorealist debate 
has meant the issue has been limited to debating the effectiveness of international institutions. Though networking among formal international organizations has critical implications for this paper, the analysis by Biermann is problematic in that the focus on formal international organizations means that the emergence of informal international organizations as autonomous variables is overlooked [Vabulus and Snidal, 2011]. The result is an inability to consider how informal international institutions feed into the network dynamic of international relations, and more to the point, of global governance. When the G20 is described as a focal point, it suggests the situation of the forum within its wider environment (the global system) as a node within this highly networked global system.

\section{"G20 as a Focal Point" at the Hangzhou Summit}

The role of the G20 as the "focal point" of global governance was underscored in the final communique that declared the G20 to be the centre of global governance for all financial and economic, social and sustainable development, and political-security matters. Geopolitical developments such as "increased refugee flows as well as terrorism and conflicts also complicate the global economic outlook" [G20 Leaders' Communique, 2016. See also Vision 20, 2016].

Initiatives such as G20 Blueprint on Innovative Growth highlight the nexus function in which linkages are consolidated between organizations with the G20 in a delegative role. Notably, the Blueprint is to be enriched by a G20 taskforce supported by the OECD and the FSB.

Primary emphasis is placed on the interaction between leaders and advisors of the "old" establishment and those of emerging countries, as illustrated by the bilateral discussions on the margin between China's Xi Jinping and Japan's Shinzo Abe.

A core strength of a focal point structure is that it allows the G20 indirectly or directly to inform and actively engage its governance by cutting across several global governance architectures at the same time. A good example is the joint ratification by the U.S. and China of the Paris Climate Change Agreement and the endorsement of the G20 Action Plan for Sustainable Development.

This role is very different from a concert role in which the G20 dictates. Indeed, the failure of the G20 to push back on the reduction of protectionist barriers or the ending of fossil fuel subsidies illustrates the G20's limitations.

The differences between the G20 as a focal point (with open access node) and a traditional closed concert are reinforced by the sharp contrast in the style of bilateral meetings. In traditional concerts one of the strengths in practical terms was the ability of leaders to have focused time together to deal with sensitive issues of mutual interest. In the G20 such meetings are often done quickly and in view of the media. Russian analysts, for example, contrasted the benefits of the traditional style with the distracted mode of operation privileged by the G20 on the Ukraine crisis. As one commentator argued as early as the 2014 Australian summit, the focal point nature of the G20 was 
detrimental to gaining results, involving as it did "numerous stakeholders including the expert community, media and the public. A transparent meetings format as well as cameras all over the summit venue used at the G20 Summit prevent frank and open communication, rather than stimulate them. National public opinion leaders and domestic opposition members essentially sit behind every G20 participant, looking for opportunities to capitalize on what could be perceived as indications of weakness. Too much friendliness with the Russian President would probably be seen that way" [Dolinskiy, 2014].

\section{What are the Effects of this Decentring on the BRICS?}

The decentred turn by the G20 certainly opens space for the BRICS, providing both a justification and a guidebook for emerging countries to both contest and build on these dynamics. As noted, it is striking how many of the operating characteristics of the BRICS resemble those of the G20. Moreover, rather than becoming eroded these features have been accentuated as witnessed by the preparations for the October Goa BRICS summit.

In terms of contestation, the BRICS continues to challenge the "ownership" of the old establishment of the IFIs. To be sure, this united challenge acts as one of the glues that helps the BRICS to operate notwithstanding a number of serious tensions. At the Hangzhou G20 the BRICS leaders also pushed for further reform of the IMF and "urged the G20 member countries in collaboration with the IMF to step up efforts to increase the institution's quota resources and review the distribution of quotas and votes to ensure fair reflection of emerging and developing economies "[BRICS Leaders' Informal Meeting, 2016) A hard target was set for the completion of the $15^{\text {th }}$ General Review of Quotas by the IMF's 2017 annual meeting.

But if the BRICS wants an elevation of status, it also wants to link the informality of the G20 to the formality of the UN. Whereas the old establishment has been prepared to go around the UN, the BRICS wants the legitimacy imprint of the UN to maintain its sense of solidarity with countries in the global South. to the Rest in the global South.

At the core of this meshing of informality with formality is the BRICS' concern at Hanzhou with a UN-focused development agenda. Meshing with the views of UN Secretary General Ban Ki-moon in a press briefing, China's focus on development for the G20 summit was endorsed. BRICS leaders also restated their commitment to implement the UN Sustainable Development Goals (SDGs).

Amid these core concerns however, the BRICS has also gone through a process of fragmentation. The NDB - despite its emphasis on green infrastructure/financing - has not been integrated into the G20 summit in order to advance the sustainable development agenda.

Instead, the BRICS has put the onus on strengthening the networking dimension. The Goa summit under India's chair will see over 50 sectoral meetings organized at the 
ministerial, official, technical and track II levels. A great effort will be on "greater people-to-people participation" with a wide number of events planned - "the BRICS Under-17 Football Tournament, BRICS Film Festival, BRICS Wellness Forum, BRICS Youth Forum, Young Diplomat's Forum, BRICS Trade Fair, BRICS Friendship Cities Conclave besides the think-tank and academic forums [Beijing Review, 2016]."

Attached closely to the G20 model, considerable attention has been placed on intergovernmental outreach. At the Fortaleza summit in 2014, Brazil invited several heads of state/government from Latin America, while at Ufa last year Russia invited the leaders of the Eurasian Economic Union and the Shanghai Cooperation Organisation. One option for India may have been to include South Asian Association for Regional Cooperation (SAARC) leaders in its outreach activities; however, to avoid having to invite Pakistan it has chosen instead to host the leaders of the seven-member Bay of Bengal Initiative for Multi-Sectoral Technical and Economic Cooperation (BIMSTEC) of which Bhutan, Bangladesh, Nepal and Sri Lanka from South Asia and Myanmar and Thailand from ASEAN are members.

As in the case of the G20, however, the fragmented process compromises the core institution-building potential of the BRICS. The Goa summit showcases this problem. Amid the expansion of network dynamics, the BRICS has eroded some of its core club attributes [Cooper, 2016]. A great strength of the BRICS has been its ability to manage internal differences, whether on UN Security Council reform or the location and contributions with respect to the NDB. At Goa, however, differences came into the open, most notably through Narendra Modi's call for the BRICS to stand united against the "mothership of terrorism." This barely-concealed reference to Pakistan undercut the BRICS' club culture in a number of ways. First, it subordinated the BRICS' agenda to Modi's domestic political agenda. Second, it prioritized declaratory statements at the expense of quiet diplomacy behind closed doors. And finally it not only forced China to choose between its alliance with Pakistan and its support for the host of the Goa summit, it also misread Russia's willingness to engage on this issue. The 109-paragraph BRICS declaration specifically named the Islamic State of Iraq and Syria (ISIS) but did not mention "cross-border terrorism," thus leaving out the groups that India was targeting [Goa Declaration, 2016].

\section{Conclusion}

This paper has showcased the dualism associated with hub/parallel dynamic around global governance. The first emphasizes the role of the G20 as a focal point for the global system. The catalyst for this approach stems from the "near death experience" of the financial shocks in late-2008 [Sorkin, 2009] when there was a palpable need for a concerted hub dynamic.

The other more competitive-oriented scenario puts the emphasis on the extension of parallel activity among individual BRICS countries, and the further institutionalization of the BRICS summit process. Here as well, despite signs of diplomatic coopera- 
tion it must be acknowledged that the BRICS is not a coherent group, and solidarity mixes with internal differences and rivalries.

The in-between prediction is that the bifurcated nature of the international system, in which both cooperation and competition are key features, will mean more messiness in the intentional system [Haass, 2010]. The instrumentality of economic complex interdependence and the symbolic importance of status enhancement motivate tactical forms of cooperation through the G20 concert. But strategically, the BRICS wants to maintain ample space for autonomous activity.

The financial crisis raised justifiable concerns about the possible collapse of the global system. It also raised expectations that the G20 would emerge as a new concert of powers that could act not just as a crisis committee but also as a steering committee for the world. Having prevented the worst-case outcome, there is still a possibility, however distant, that the steering approach could emerge with attendant advances in global governance. The global system is in the midst of a protracted period of discontinuity characterized by profound and intense tension between the push for a consolidated form of institutional synergy (with the G20 as the hub focal point) and the pull towards potential fragmentation (with the BRICS as the core agent of change). The nature and impact of this dynamic will animate the central debate over global governance in the $21^{\text {st }} \mathrm{C}$.

\section{References}

Alexandroff, A.S. and A.F. Cooper, eds. (2010). Rising States, Rising Institutions: Can the World Be Governed? Washington, DC: Brookings Institution Press.

Angeloni, Ignazio and Jean Pisani-Ferry (2012). "The G20: Characters in Search of an Author.” Bruegel Working Paper.

Baker, Andrew (2010). "Deliberative International Financial Governance and Apex Policy Forums: Where We Are and Where We Should be Headed.” In: Geoffrey R.D. Underhill, Jasper Blom and Daniel Mügge, eds., Global Financial Integration Thirty Years On; from reform to crisis. Cambridge: Cambridge University Press.

Barma, N.H., Ratner, E. and Weber, S. (2007) "A World Without the West," The National Interest, vol. 90 (July/August), no 23-30.

Beijing Review (2016), No. 39. 29 September. Available at: http://www.bjreview.com/Opinion/201609/ t20160926_800068243.html (accessed July 2017).

Biermann, Frank, Philipp Pattberg, Harro van Asselt and Fariborz Zelli (2009). "Fragmentation of Global Governance Architectures: A Framework for Analysis." Global Environmental Politics 9 (4), pp. 14-40.

Biermann, R. (2008) "Towards a theory of inter-organizational networking: The Euro-Atlantic security institutions interacting," Review of International Organization, no 3, pp. 151-177. doi:10.1007/s11558007-9027-9.

BRICS Leaders' Informal Meeting on the Margins of the G20 Summit (2016) Hangzhou, China, 4 September 2016. Media Note. Available at: http://www.fmprc.gov.cn/mfa_eng/zxxx_662805/t1394397. shtml (accessed July 2017).

Brummer, Chris (2012). Soft Law and the Global Financial System: Rule Making in the 21st Century. New York: Cambridge University Press. 
Chin, Gregory (2010). "Remaking the Architecture: The Emerging Powers, Self-Insuring and Regional Insulation.” International Affairs 86 (3), pp. 693-715.

Cooper, Andrew F. (2010) "The G20 as an improvised crisis committee and/or a contested 'steering committee' for the world." International Affairs 86 (3), pp. 741-757. Available at: http://www.chathamhouse.org/sites/default/files/public/International\%20Affairs/2010/86_3cooper.pdf (accessed July 2017).

Cooper, Andrew F. (2012). The Group of Twenty: Input and Output Legitimacy, Reforms, and Agenda. ADBI Working Paper (372) 25 August.

Cooper, Andrew F. (2013). "Civil Society Relationships with the G20: An Extension of the G8 Template or Distinctive Pattern of Engagement?” Global Society 27 (2), pp. 179-200.

Cooper, Andrew F. (2016). The BRICS:VSI. Oxford: OUP.

Cooper, Andrew F. and Antkiewicz, Agata, eds. (2008). Emerging Powers in Global Governance: Lessons from the Heiligendamm Process. Waterloo: Wilfred Laurier University Press.

Cooper, Andrew F. and Vincent Pouliot (2015) "How much is global governance changing? The G20 as international practice." Cooperation and Conflict 50 (3), pp. 334-350.

Cooper, Andrew F. and Bessma Momani (2014). "Re-balancing the G-20 from Efficiency to Legitimacy: The 3G Coalition and the Practice of Global Governance." Global Governance: A Review of Multilateralism and International Organizations 20(2), pp. 213-232.

Cooper, Andrew F. and Colin Bradford (2010). The G20 and the Post-Crisis Economic Order. Centre for International Governance Innovation G20 Paper (3) 10 June.

Cooper, Andrew F. and Ramesh Thakur (2013). The Group of Twenty (G20). New York: Routledge.

Dingwerth, Klaus and Philipp Pattberg (2006). "Global Governance as a Perspective on World Politics." Global Governance 12, pp. 185-203.

Dolinskiy, Alexey (2014). "What the G20 Summit Means for Russia and Ukraine." Russia Direct, 17 November. Available at: http://www.russia-direct.org/opinion/what-g20-summit-means-russia-andukraine (accessed July 2017).

G20 Leaders' Communique (2016) Hangzhou Summit, 4-5 September. Available at: http://www.fmprc. gov.cn/mfa_eng/zxxx_662805/t1395000.shtml (accessed July 2017).

Garrett, Geoffrey and Barry R. Weingast (1993). "Ideas, Interests and Institutions.” In: Judith Goldstein and Robert O. Keohane, eds., Ideas \& Foreign Policy: Beliefs, Institutions and Political Change. Ithaca, NY: Cornell University Press.

Goa Declaration at 8th BRICS Summit (2016). Ministry of External Affairs, Government of India, 16 October. Available at: http://www.mea.gov.in/bilateral-documents.htm?dtl/27491/Goa+Declaration+at+8th+BRICS+Summit (accessed July 2017).

Haass, R.N. (2010) “The Case for Messy Multilateralism," Financial Times, January 5.

Ikenberry, G. John (2001). After Victory: Institutions, Strategic Restraint, and the Rebuilding of Order after Major Wars. Princeton, NJ: Princeton University Press.

Kirton, John J. (1989). The Significance of the Seven-Power Summit. University of Toronto G8 Information Center. Available at: http://www.g8.utoronto.ca/scholar/kirton198902/index.html (accessed July 2017).

Kirton, John J. (2013). G-20 Governance for a Globalized World. Aldershot: Ashgate.

Luckhurst, J. (2016). G20 Since the Global Crisis. New York: Routledge.

Martin, Paul (2013). "The G20: From Global Crisis Responder to Steering Committee.” In: Andrew F. Cooper, Jorge Heine and Ramesh Thakur, eds., The Oxford Handbook of Diplomacy. Oxford: Oxford University Press.

Pentilla, R. (2009) “Multilateralism light: The rise of informal international governance," London: Centre for European Reform. Available at: http://wwwcer.org.uk/publications/archive/essay/2009/multilateralism-light-rise-informal-international-governance (accessed July 2017). 
Schirm, Stefan A. (2011). "Global Politics are Domestic Politics: How Societal Interests and Ideas Shape Ad Hoc Groupings in the G20 Which Supersede International Alliances." Paper prepared for International Studies Association. Available at: http://www.sowi.rub.de/mam/content/lsip/schirmg20isa2011.pdf (accessed July 2017).

Sorkin, Andrew Ross (2009) "Wall Street's Near-Death Experience.” 5 October. Available at: http: www. vanityfair.com/news/2009/11/too-big-to-fail-excerpt-200911(accessed July 2017).

Vabulas, Felicity and Duncan Snidal (2011). "Informal Intergovernmental Organizations (IIGOs)." Draft paper prepared for submission to the PEIO Conference, Villanova University, 22-28 January 2012. Available at: http://147.142.190.246/joomla/peio/files2012/papers/Vabulas\%2029.09.11.pdf (accessed July 2017).

Vision 20 (2016). "Give the World Hope: G20 Leadership for People-Centered Inclusive and Sustainable Growth." A Blue Report for the G20 Presidency 2016. Available at: http://iar2015.sites.olt.ubc.ca/ files/2016/07/V20-Blue-Report_July22_public-1.pdf (accessed July 2017). 


\title{
Между статусом хаба и параллельной деятельностью: исследование роли «Группы двадцати» и БРИКС в глобальном управлении ${ }^{1}$
}

\author{
Э.Ф. Купер
}

Купер Ф. Эндрю - профессор, Факультет политических наук и Школа международных отношений Бэлсилли, Университет Ватерлоо; 200 University Ave West, Waterloo, Ontario, Canada; E-mail: acooper@uwaterloo.ca

«Группа двадиати» должна позиционироваться в системе глобального управления во все более децентрализованной манере. Ранее «двадиатка» в основном воспринималась как концерт держав ХХІ в., однако, как свидетельствует динамика продолжающихся процессов в рамках института, она становится все более фрагментированной. «Группа двадиати» трансформировалась из главного форума клубного типа в системе глобального управления в координационный центр («фокальную точку»). Ключевое значение в этом процессе децентрализации сыграл БРИКС. Помимо участия этой группы восходящих держав в деятельности «двадцатки» в качестве хаба глобального управления, они также инициируют разнообразные параллельные инициативы. Деятельность «двадиатки» и БРИКС отличается некоторыми общими чертами, связанными с их неформальным характером. На фоне укрепления роли сетевых форумов увеличивается разнообразие направлений их деятельности и число участвующих в ней государственных и негосударственных субъектов. Одновременно децентрализаиия представляет вызов для клубной культуры «двадиатки» и БРИКС, поскольку снижается уровень единомыслия участников, характерный для традиционных «концертов» держав.

Хотя данная работа носит концептуальный характер, в ней содержатся некоторые иллюстрации из недавней практики, в том числе саммита «двадиатки» в Ханчжоу и саммита БРИКС на Гоа. Глобальная система находится в середине длительного периода дискретности, сопровождающегося сильными и интенсивными маятниковыми движениями от консолидированной формы институционального сотрудничества (через «двадиатку» как «фокальную точку») к растущей фрагментации (при ключевой роли БРИКС в этих изменениях). Различия между двумя этими формами будут основным поводом для дискуссий о глобальном управлении в ХХІ в.

Ключевые слова: «Группа двадцати»; БРИКС; глобальное управление; саммит; Ханчжоу; Гоа

Для цитирования: Купер Э.Ф. Между статусом хаба и параллельной деятельностью: исследование роли «Группы двадцати» и БРИКС в глобальном управлении // Вестник международных организаций. 2017. Т. 12. № 2. C. 146-163. DOI: 10.17323/1996-7845-2017-02-146

\section{Литература}

Alexandroff A.S., Cooper A.F. (eds) (2010) Rising States, Rising Institutions: Can the World Be Governed? Washington, D.C.: Brookings Institution Press.

Angeloni I., Pisani-Ferry J. (2012) The G20: Characters In Search of an Author. Bruegel Working Paper 2012/04.

\footnotetext{
${ }^{1}$ Статья поступила в редакцию в декабре 2016 г.
} 
Åslund A. (2009) The Group of 20 Must be Stopped // Financial Times. 26 November.

Baker A. (2010) Deliberative International Financial Governance and Apex Policy Forums: Where We are and Where we Should be Headed // Global Financial Integration Thirty Years On: From Reform to Crisis / Geoffrey R.D. Underhill, J. Blom, D. Mügge (eds). Cambridge: Cambridge University Press.

Biermann F., Pattberg P., Harro van Asselt F.Z. (2009) Fragmentation of Global Governance Architectures: A Framework for Analysis // Global Environmental Politics. Vol. 9. No. 4. P. 14-40.

Barma N.H., Ratner E., Weber S. (2007) A World Without the West // The National Interest. Vol. 90 (July/August). No. 23-30.

Beijing Review (2016) Better Together. No. 39. 29 September. Режим доступа: http://www.bjreview. com/Opinion/201609/t20160926_800068243.html (дата обращения: 20 июля 2017).

Biermann R. (2008) Towards a Theory of Inter-organizational Networking: The Euro-Atlantic security institutions interacting // Review of International Organizations. No. 3. P. 151-177. DOI: 10.1007/ s11558-007-9027-9.

BRICS Leaders(2016) Informal Meeting onthe Margins of the G20 Summit Hangzhou. China, 4September. Режим доступа: http://www.fmprc.gov.cn/mfa_eng/zxxx_662805/t1394397.shtml (дата обращения: 20 июля 2017).

BRICS (2016) Goa Declaration at 8th BRICS Summit. 16 October. Режим доступа: https://www.mea. gov.in/bilateral-documents.htm?dtl/.../Goa+Declaration+at...BRICS (дата обращения: 05.04.2017).

Brummer C. (2012) Soft Law and the Global Financial System: Rule Making in the 21st Century. N. Y.: Cambridge University Press.

Chin G. (2010) Remaking the Architecture: The Emerging Powers, Self-Insuring and Regional Insulation // International Affairs. No. 86 (3). P. 693-715.

Cooper A.F. (2010) The G20 as an Improvised Crisis Committee and/or a Contested 'Steering Committee' for the World // International Affairs. No. 86 (3). P. 741-757. Режим доступа: http://www. chathamhouse.org/sites/default/files/public/International\%20Affairs/2010/86_3cooper.pdf (дата обращения: 05.04.2017).

Cooper A.F. (2012) The Group of Twenty: Input and Output Legitimacy, Reforms, and Agenda // ADBI Working Paper. No. 372. 25 August. Tokyo: Asian Development Bank Institute.

Cooper A.F. (2013) Civil Society Relationships with the G20: An Extension of the G8 Template or Distinctive Pattern of Engagement? // Global Society. No. 27 (2). P. 179-200.

Cooper A.F. (2016) The BRICS: A Very Short Introduction. Oxford, OUP.

Cooper A.F., Antkiewicz A. (eds) (2008) Emerging Powers in Global Governance: Lessons from the Heiligendamm Process. Waterloo: Wilfred Laurier University Press.

Cooper A.F., Bradford C. (2010) The G20 and the Post-Crisis Economic Order // CIGI G20 Paper. No. 3. 10 June.

Cooper A.F., Momani B. (2014) Re-balancing the G-20 from Efficiency to Legitimacy: The 3G Coalition and the Practice of Global Governance // Global Governance: A Review of Multilateralism and International Organizations. No. 20 (2). P. 213-232.

Cooper A.F., Pouliot V. (2015) How much is Global Governance Changing? The G20 as Iternational Practice // Cooperation and Conflict. No. 50 (3). P. 334-350.

Cooper A.F., Thakur R. (2013) The Group of Twenty. N. Y.: Routledge.

Dingwerth K., Pattberg P. (2006) Global Governance as a Perspective on World Politics // Global Governance. No. 12. P. 185-203.

Dolinskiy A. (2014) What the G20 Summit Means for Russia and Ukraine // Russia Direct. 17 November.

G20 Leaders' Communique (2016) Hangzhou Summit 4-5 September. Режим доступа: www.fmprc. gov.cn/mfa_eng/zxxx_662805/t1395000.shtml (дата обращения: 05.04.2017). 
Garrett G., Weingast B.R. (1993) Ideas, Interests and Institutions // Ideas \& Foreign Policy: Beliefs, Institutions and Political Change / J. Goldstein, R.O. Keohane (eds). Ithaca, NY: Cornell University Press.

Goa Declaration at 8th BRICS Summit (2016) Ministry of External Affairs, Government of India, 16 October. Режим доступа: http://www.mea.gov.in/bilateral-documents.htm?dtl/27491/Goa+Declar ation+at+8th+BRICS+Summit (дата обращения: 20 июля 2017).

Haas R.N. (2010) The Case for Messy Multilateralism // Financial Times. 5 January.

Ikenberry G.J. (2001) After Victory: Institutions, Strategic Restraint, and the Rebuilding of Order after Major Wars. Princeton, NJ: Princeton University Press.

Kirton J.J. (2013) G-20 Governance for a Globalized World. Aldershot: Ashgate.

Kirton J.J. (1989) The Significance of the Seven-Power Summit. University of Toronto G8 Information Center. Режим доступа: http://www.g8.utoronto.ca/scholar/kirton198902/index.html (дата обращения: 20.07.2017).

Luckhurst J. (2016) G20 Since The Global Crisis. N. Y.: Routledge.

Martin P. (2013) The G20: From Global Crisis Responder to Steering Committee // The Oxford Handbook of Diplomacy / A.F. Cooper, J. Heine, R. Thakur (eds). Oxford: Oxford University Press.

Martinez-Diaz L., Woods N. (2009) The G20 - the Perils and Opportunities of Network Governance for Developing Countries. November. Режим доступа: http://www.odi.org.uk/sites/odi.org.uk/files/odiassets/events-documents/3714.pdf (дата обрашения: 05.04.2017).

Pentilla R. (2009) Multilateralism Light: The Rise of Informal International Governance. London: Centre for European Reform. Режим доступа: http://wwwcer.org.uk/publications/archive/essay/2009/ multilateralism-light-rise-informal-international-governance (дата обращения: 05.04.2017).

Riveros L.A. (2011) The G-20 Economies and the Financial Crisis: Concerns over Governance. RIBEI Working Paper 41.

Rodrik D. (2011) The Globalization Paradox: Democracy and the Future of the World Economy. N. Y.: W.W. Norton and Company.

Schirm S.A. (2011) Global Politics are Domestic Politics: How Societal Interests and Ideas Shape ad hoc Groupings in the G20 which Supersede International Alliances. Paper prepared for International Studies Association. Режим доступа: http://www.sowi.rub.de/mam/content/lsip/schirmg20isa2011.pdf (дата обращения: 05.04.2017).

Slaughter A.-M. (2004) A New World Order. Princeton, NJ: Princeton University Press.

Sorkin A.R. (2009) Wall Street's Near-Death Experience, 5 October. Режим доступа: http://www.vanityfair.com/news/2009/11/too-big-to-fail-excerpt-200911 (дата обращения: 20.07.2017).

Vabulas F., Snidal D. (2012) Informal Intergovernmental Organizations (IIGOs). Draft paper prepared for submission to the PEIO Conference, Villanova University, 22-28 January. Режим доступа: http://147.142.190.246/joomla/peio/files2012/papers/Vabulas\%2029.09.11.pdf (дата обрашения: 05.04. 2017).

Vision 20-The Hangzhou G20 Summit (2016) A Blue Report to the G20 Presidency. 19 Мау. Режим доступа: iar.ubc.ca/v20-blue-paper-now-released/ (дата обращения: 05.04.2017).

Weber S., Barma N., Ratner E. (2007) A world Without the West // National Interest. No. 90 (July/ August). P. 23-30. 